International Journal of

\title{
A study of anthropometric measurements, body composition and somatotyping of high jump and shot put athletes
}

\section{KRISHNA R. YADAV}

Received : 17.07.2014; Revised : 10.09.2014; Accepted : 23.09.2014

\footnotetext{
Author for correspondence : KRISHNA R. YADAV

M.V.A.S. Shri K.G. Nadgir College of Physical Education, DHARWAD

(KARNATAKA) INDIA

Email: krishnayadav1237@

yahoo.com
}

\section{- ABSTRACT}

The purpose of the study was to compare the Anthropometric characteristics, Body composition and Somatotyping in male High jump $(\mathrm{N}=10)$ and Shot Put athletes $(\mathrm{N}=10)$ of different colleges affiliated to Karnatak University, Dharwad state of: Karnataka, The age of athletes was between 18 to 25 years. All subjects were assessed for height, weight, breadth, girth and skinfold thickness. Percentage of fat was calculated from the sum of 4 measurements of skinfold thickness. The independent samples t-test revealed that, high jump athletes had significantly Higher height $(\mathrm{p}<0.01)$, Body mass index $(\mathrm{p}<0.05)$, Total leg length $(p<0.01)$ and Total arm length $(p<0.01)$ as compared to Shot Put athletes, but their weight $(p>0.01)$ was significantly lower as compared to Shot Put athletes. The Shot Put athletes had significantly greater in two girths, Bi-humerus $(\mathrm{p}<0.01)$ and Bi-femur $(\mathrm{p}<0.01)$ diameters, as compared to high jump athletes, where as high Jump athletes had lean body mass $(\mathrm{p}<0.01)$ and mesomorphic score $(\mathrm{p}<0.01)$ as compared to Shot put athletes. The Shot put athletes found to have significantly higher per cent body fat $(\mathrm{p}<0.05)$ and Mesomorphic $(\mathrm{p}<0.01)$ score than the high jump athletes. It is concluded that, in most of the parameters there were significant differences between high jump and shot put athletes. The shot put athletes showed better anthropometric measurements and somatotyping scores.

- Key Words : Anthropometry, Somatotype, Body fat, Body mass, Athletes

- How to cite this paper : Yadav, Krishna R. (2014). A study of anthropometric measurements, body composition and somatotyping of high jump and shot put athletes. Internat. J. Phy. Edu., 7 (2) : 67-70. 